\title{
Parents and Young Learners' Metaphorical Perceptions about Learning English
}

\author{
Abdullah Coşkun \\ Correspondence: Abdullah Coşkun, School of Foreign Languages, Abant Izzet Baysal University, Bolu, Turkey
}

Received: June 23, 2015 Accepted: August 3, $2015 \quad$ Online Published: August 4, 2015

doi:10.11114/jets.v3i5.1015 URL: http://dx.doi.org/10.11114/jets.v3i5.1015

\begin{abstract}
By means of the metaphoric language used by parents and young English as a foreign language (EFL) learners to describe the English learning process, this study aims to reveal the perceptions of 109 young EFL learners in the 8th grade of secondary school and 66 parents in Turkey about learning English. To elicit these participants' metaphors, they were asked to complete the gaps in the sentence "Learning English is like...because..." The emerging similar metaphors and the related justification were categorized under the predetermined categories (i.e., positive, negative, ambivalent and neutral metaphors), and some representative metaphors of the participants were illustrated under each category. Besides, to investigate whether there is any significant relationship between the numbers of positive/negative metaphors produced by 66 parents and their children attending the 8th grade, the Pearson correlation coefficient was calculated. The findings of the study revealed that parents were generally more positive than learners about the English language learning process. In contrast, the majority of learners produced negative metaphors such as "Learning English is like being able to walk on the water because both walking on the water and learning English are impossible" although some of them used metaphors such as "a skeleton key" to underline the utility of learning English. It was also found that there is a significant relationship between the numbers of positive/negative metaphors created by parents and their children about the English language learning process. At the end of this paper, some recommendations are made for young EFL learners, their teachers and parents for the improvement of the learning/teaching environment of the young EFL learners in Turkey. It is believed that studies dealing with metaphors held by parents and learners can pave the way for a better understanding of the challenges faced in the foreign language learning process, and necessary actions can be taken so that a more effective learning atmosphere can be created.
\end{abstract}

Keywords: metaphors, learning English

\section{Introduction}

The word "teaching" provokes in mind the image of the teacher while "learning" is mostly considered a student-centered activity mainly depending upon the beliefs, attitudes and motivation of the learner. Thus, in order to create a successful English language learning environment, it is important to know the learners' perceptions of how they feel about learning the English language. The perceptions of the language learners have been under investigation by many researchers since the beginning of the new Millennium (Berry, 2004; Fortune, 2005; Liao, 2006) to essentially be able to find out the sources of challenges or failure and relevant solutions likely to lead to the creation of a more effective foreign language learning atmosphere.

As rightly argued by Şaban (2004), one can gain insights into learners' cognition and reveal their learning problems, the causes of the problems and their classroom experiences by investigating their perceptions, which in turn is expected to contribute to the improvement of the quality of their learning in general. Similarly, many researchers in the field of foreign language learning and teaching underlined the need to uncover learners' beliefs about learning the language because they believe that these beliefs affect their learning (Aragao, 2011). One way of revealing beliefs related to learning the language is through metaphors defined by Lakoff and Johnson (1980) as expressions reflecting our perceptions and actions. It is also argued that metaphors are the guides of our perceptions (Cornelissen, Oswick, Christensen \& Phillips, 2008) and our perceptions affect our language learning performance (Gardner, 1985).

Pertaining to the use of metaphors in linguistics, Lakoff and Johnson (1980) highlighted long ago that metaphors reveal deeper perceptions of people on different concepts. In recent studies, it is also underlined that metaphors are powerful mental instruments that can be used to express high level, abstract, complex and theoretical concepts and issues (Yob, 
2003). Therefore, in order to develop a better understanding of learners' views about language learning, metaphors have been widely used in the field of foreign language education (Kesen, 2010), and the effectiveness of metaphors as a research tool has been proven in qualitative research studies carried out not only in Turkey (Çapan, 2010; Önen \& Koçak, 2011) but also abroad (Cochran, 2002; Goldstein, 2005). Investigating young EFL learners and parents' metaphorical perceptions of the English learning process in Turkey, this study has the main objective to shed some light on their conceptualization of English learning, and to find out whether the majority of them hold positive or negative attitudes toward this process. After the presentation of local and international literature dealing with metaphors as a data collection tool, the method and the results of the current study are provided. At the end of the paper, some recommendations are made for the improvement of teaching EFL for young learners.

\subsection{Literature Review}

The review of literature involving the use of metaphor as a research technique in the field of foreign language education indicates that there have been plenty of studies focusing on the English teachers' roles in different contexts of the world. For instance, Nikitina and Furouka (2008) concentrated on the metaphors produced by a group of Malaysian adult learners about the teachers' role in the classroom. They found that their participants regarded their English teachers as givers and caretakers. In another study, Torghabeh, Elahi and Khanalipour (2009) obtained metaphors from Iranian students and categorized the metaphors under conceptual metaphors such as organizer, spiritual leader, parent, innovator provider of knowledge, entertainer, nurturer, counselor and friend. In a similar vein, De Guerrero and Villamil (2002) collected metaphors of English teachers in Puerto Rico and came up with categories like provider of tools, nurturer, innovator, agent of change, teacher as cooperative leader and gym instructor. On the other hand, in China, students and EFL teachers' metaphors were investigated and categorized by Wan, Low and Li (2011) under the following categories: interest arouser, co-worker, culture transmitter, teacher as provider, devotee, instructor, nurturer and authority.

In addition to the image of the teacher from the perspective of both students and teachers, there have been other studies abroad in line with the present study aiming to uncover how the English learning process is perceived. To illustrate, Cortazzi and Jin (1996, as cited in Oxford et al., 1998) focused on the metaphors created by students and teachers related to their experiences and they reached metaphorical categories such as journey, cooking, plant growth, cultivation and search for treasure. Similarly, Caballero (2006) found that the journey metaphor was highly used by his participants. In another study in the same vein, Ellis (2002) studied adult foreign language learners in German courses. The metaphors included in the diaries kept by the learners were examined, and the following metaphorical categories were found: journey, puzzle, work, suffering and struggle. He highlighted that the most frequently produced metaphor was also "learning as a journey" metaphor through which students were able to express the challenges they encountered during the language learning process. In Jin et al.'s (2014) study, the English learning motivation of Chinese primary school learners was analyzed by means of the metaphors they produced. They found that the learners were very positive about learning English and felt happy and excited to learn the language; in addition, learners believed in the merits of interactive methods and learning through play. It was also revealed in their study that some young learners were aware of the difficulties of learning English, but were confident to achieve their English learning targets despite these challenges.

On the other hand, there are some studies based on the analysis of the elicited metaphors in the Turkish EFL context. For example, Şimşek (2014) analyzed the metaphors of prospective English teachers at a pre-service teacher training department of a Turkish university. It was revealed that most of the participants accepted the interactional and functional views of language. Another study was carried out by Seferoğlu, Korkmazgil and Ölçü (2009) who collected data from junior and senior pre-service teachers as well as in-service teachers about their beliefs of what an English teacher is like. The metaphors used by these groups were as follows: teacher as leader, teacher as producer, teacher as resource person, teacher as care-taker, teacher as guide, teacher as facilitator. In another study, Çap and Acat (2012) aimed to collect metaphors from secondary school learners about how they feel about their English learning process. The categories they reached at the end of their analysis revealed significant differences caused by the participants' class level and gender. In her study, Aktekin (2013) mainly explored learners' metaphorical perceptions about their language learning process. She concluded that most of the learners created metaphors that can be categorized under "Activity which requires practice and/or patience." She justified this category by giving the metaphorical example "driving a car". At the end of her paper, she concludes that metaphors are valuable as they give an idea pertaining to the foreign language learning process.

To the best knowledge of the researcher, although there have recently been many local and international studies focusing on the English teachers' metaphorical language about the teaching-learning process, (e.g., Seferoğlu, et al., 2009, Şimşek, 2014, De Guerrero \& Villamil, 2002) and on perceptions of adult EFL learners (Ellis, 2002; Aktekin, 2013; Nikitina \& Furouka, 2008), a study aiming to reveal both the young EFL learners and their parents' metaphorical perceptions related to the English learning process has not yet been carried out in Turkey. Therefore, the current 
research paper mainly aims to uncover the metaphors parents and young EFL learners produce about learning the English language and to reveal their justification of these metaphors. There is a need for such a study because as rightly argued by Arıkan (2015), there is a lack of empirical research studies in Turkey dealing with young EFL learners. It is also believed that revealing the metaphors of learners and parents getting actively involved in the learning process can contribute to a positive change in educational beliefs and practices (Cameron, 2003) because necessary actions can be taken to cope with the negative metaphors and to turn these metaphors into positive ones. It is believed that the metaphors held by young learners as well as their parents about the nature of learning English can give valuable insights to the English teachers (Ellis \& Barkhuizen, 2005) and to other relevant stakeholders such as EFL curriculum designers, materials developers and the decision-makers (e.g., National Ministry of Education) about ways of overcoming problems encountered by learners and parents in the English learning process.

The rationale behind the involvement of parents in this study can be justified by referring to the close connection between the positive attitudes of parents and children's success (Roth, 2008; Clark \& Hawkins, 2010; Cooper \& Maloof, 1999). It is argued by Eroz and Akbarov (2014) that in education, learners' success depends very much on a triangle whose parts are the teacher, learner and the parent; moreover, parents share an important responsibility to help their children while learning the language.

In line with the aims of the study, the following research questions have been formulated:

1. What are the metaphors produced by parents of young EFL learners about learning English?

2. What are the metaphors produced by young EFL learners about learning English?

3. Is there any significant relationship between the numbers of positive/negative metaphors produced by parents and their children?

\section{Method}

\subsection{Participants and Data Collection}

In this study, the reason why the metaphoric language created by young learners was used is that metaphors in studies involving young learners have proved useful as they generally have difficulties in explaining abstract ideas at a deeper level (Jin et al., 2013). The data for this study was elicited through metaphors because metaphors include varied expressions that pave the way for the researcher to be able to make categorization under certain thematic categories taking the differences and similarities of the metaphors into account (Yıldırım \& Şimşek, 2005).

One hundred nine young EFL learners attending 8th grade classes in two different state secondary schools in Turkey were reached at the end of the academic year. Only the students in the classrooms whose teachers indicated that they had already finished the lessons to be covered by the end of the school year took part in the study. The teachers were consulted to learn whether their schedule was flexible enough to allocate time for this study. As the participants were young learners, they were first given a metaphor example (i.e., My mother is like an angel because she is always with me) in Turkish to help them understand what a metaphor is. Then, all the participating learners were given a sheet of paper on which the stem 'Learning English is like...because...' was written in Turkish and they were asked to perform this sentence completion task by filling in the first blank with a metaphor and the second blank with the entailment described by Jin et al. (2013) as the justification of a metaphor.

In order to analyze the relationship between parents and their children's perceptions, parents' metaphors were also investigated. After the data were collected from 109 learners in two different schools in the city, learners in one of the schools were asked to distribute the sentence completion task to their parents and ask them to produce metaphors about learning English at the back of the sheet whose front was used to write metaphors by their children. Learners were asked to bring the sheets to their teachers in the following lesson so that a comparison of the metaphorical categories of learners and their parents could be made. To explore the relationship between positive and negative metaphors of parents and learners, participating learners were asked to use the front page of the sheet while parents used the back of the same sheet. Sixty-six parents (father or mother) whose children were attending the 8th grade performed the sentence completion task in Turkish. Both parents and learners' metaphors were then translated into English.

\subsection{The Education System and EFL Education in Turkey}

For a better understanding of the context where the data for the present study were collected, there is a need to present concisely the basics of the education system and more specifically EFL education in Turkey. As summarized by Gürsoy, Korkmaz and Damar (2013), the compulsory education in Turkey was increased from eight years to 12 years with an educational reform introduced as the $4+4+4$ education reform in 2012, and the starting age for primary school was lowered to 66 months of age. The duration of the primary, secondary and high school was determined as four years for each. Accordingly, the learners taking part in this study are in the last grade of the secondary school and this group of 
language learners is defined by Ersöz (2007) as older/late young learners.

In the education context of Turkey, one of the most debatable aspects of the education is teaching EFL. Many researchers attract attention to the fact that the expected level of English cannot be achieved in our country and learners cannot be competent enough in English despite all the efforts (Çelebi, 2006; Kırkgöz, 2008; Işık, 2008; Arıkan, 2011, 2015; TEPAV \& British Council, 2014). Therefore, a new EFL teaching curriculum was put into action by the National Ministry of Education in the 2013-2014 academic year, and English language courses were added into the programs of primary school 2nd graders, which made it possible for learners to start learning English earlier. Previously, students in Turkey used to start learning English in the 4th grade. The main aim of this program offering English instruction to young learners between the 2nd and 8th grades in primary and secondary schools in Turkey is to create a motivating learning environment for young EFL learners so that they can feel comfortable while learning the language (T.C. Milli Eğitim Bakanlığı, 2013).

In the new program, the curriculum of the 8th grade young learners, who are the participants of the current study, aims to increase learners' English proficiency level to A2 (Basic User) as described in the Common European Framework of Reference (CEFR) providing "a common basis for the elaboration of language syllabuses, curriculum guidelines, examinations, textbooks, etc. across Europe" (Council of Europe, 2001:1). The primary focus of the curriculum for this grade is on listening and speaking and the secondary emphasis is on reading and writing. The number of English lessons is four per week in the 8th grade in secondary schools in Turkey.

\subsection{Data Analysis}

Both qualitative and quantitative data analysis techniques were applied in the study. The qualitative data was analyzed in line with Cameron and Low's (1999) methodology of metaphor analysis. First, the metaphors were listed, and then they were broken down into analyzable pieces to determine similarities. Finally, exemplar metaphors were assigned to a category and entailments were investigated to reveal the participants' justification of the metaphors (Guerrero \& Villamil, 2002). The metaphors and entailments obtained from the parents and learners were classified into predetermined categories such as positive, negative, neutral or ambivalent metaphors according to their perceptions about the English learning process as in Jin et al.'s (2014) study. The semantically related metaphors were grouped together under the same category. While positive and negative metaphors related to English leaning are self-explanatory, it is important to clarify neutral metaphors which describe factual issues to explain learners' views with no personal judgment. On the other hand, ambivalent metaphors are those expressing a dilemma in what learning English means to the learners. In addition, the quantitative data were reached by calculating the percentages of metaphorical categories (i.e., positive, negative, neutral or ambivalent). Additionally, to explore the correlation between the numbers of positive/negative metaphors produced by parents and their children, Pearson coefficient correlation analysis was conducted using the Statistical Package for Social Sciences (SPSS).

\section{Results}

Firstly, the percentages of participants making similar metaphorical comments are presented below in Figures 1 and 2. Then, parents and learners' metaphors and entailments categorized as positive, negative, neutral or ambivalent metaphors are separately discussed. Finally, the results pertaining to the correlation between parents and students' positive and negative perceptions about learning English are illustrated. Figure 1 presents the distribution of metaphorical categories of the parents taking part in the study. As can be seen in Figure 1, the majority of parents ( $\mathrm{n}=32$, $48 \%$ of all the parents) had positive perceptions regarding the English learning process. On the contrary, as illustrated in Figure 2, most of the young learners $(\mathrm{n}=49,45 \%$ of all the learners) created negative metaphors regarding learning English. The percentages of the other metaphorical categories were found to be more or less the same.

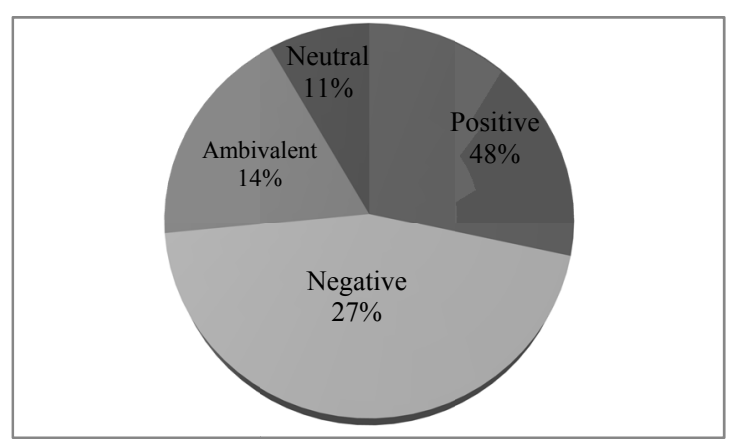

Figure 1. Parents' Metaphors Regarding English Learning

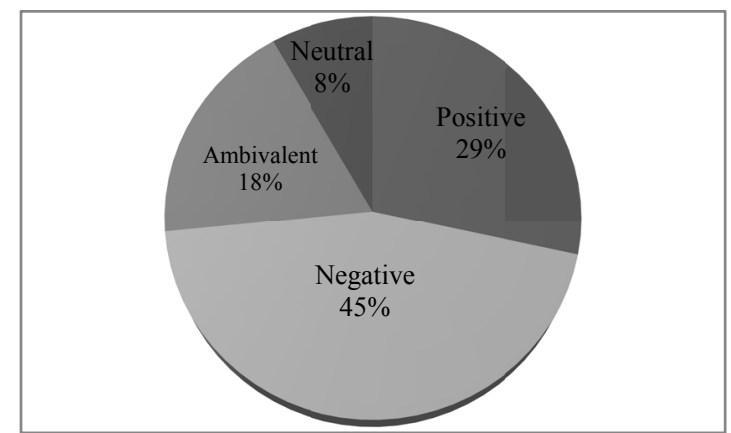

Figure 2. Learners' Metaphors Regarding English Learning 


\subsection{Parents' Metaphors}

The first research question of the study is "What are the metaphors produced by parents of young EFL learners about learning English?" Out of 66 parents participating in the study, almost half $(\mathrm{n}=32,48 \%)$ produced positive types of metaphors and entailments.

As summarized in Table 1, most of the metaphors they created regarding the English learning process were related to the necessity of English in the globalized world. Some of their other metaphors (e.g, Discovering new things) emphasize the use of the English language as a tool to learn about different people and cultures.

Table 1. Parents' Positive Metaphors Regarding English Learning

\begin{tabular}{cl}
\hline Metaphor & \multicolumn{1}{c}{ Entailment } \\
\hline ID card & You need it wherever you go. If you cannot speak \\
English, you are in trouble. & You can communicate with people all over the world \\
using English. & Without English, you cannot do anything. \\
Breathing & As the Turkish saying goes, "One language is one \\
person, two languages are two people". & You discover new things all the time while learning \\
Becoming a second person & English. And you can learn about different cultures, \\
& ways of thinking and new people using your English. \\
\hline
\end{tabular}

As can be realized in Table 2, the second largest group of parents $(n=18,27 \%)$ produced negative metaphors highlighting the difficulty of learning the language.

Table 2. Parents' Negative Metaphors Regarding English Learning

\begin{tabular}{cl}
\hline Metaphor & \multicolumn{1}{c}{ Entailment } \\
\hline Sand & The things you have to learn never ends. \\
Life itself & It is a long and arduous process. \\
Walking on a hill with many obstacles & You encounter with many challenges before you can \\
& reach the summit. \\
The human being & It is hard to deal with him/her. \\
\hline
\end{tabular}

As far as metaphors expressing a dilemma are concerned, it was found that nine parents (14\%) came up with ambivalent metaphors. These metaphors illustrated in Table 3 indicate that the English language learning process is at first challenging but later rewarding when you learn it.

Table 3. Parents' Ambivalent Metaphors Regarding English Learning

\begin{tabular}{cl}
\hline Metaphor & \multicolumn{1}{c}{ Entailment } \\
\hline Fasting & $\begin{array}{l}\text { You might feel tired while doing it. But at the end, you } \\
\text { will get the reward. } \\
\text { Everywhere gets dark, it rains but finally the rainbow } \\
\text { appears. }\end{array}$ \\
The emergence of the rainbow & $\begin{array}{c}\text { It seems difficult at first. You will enjoy it after you } \\
\text { learn how to drive. }\end{array}$ \\
\hline
\end{tabular}

As can be understood from Table 4, only seven (11\%) parents were found to be neutral about the learning process and underlined the general nature of the English learning process without expressing emotional comments.

Table 4. Parents' Neutral Metaphors Regarding English Learning

\begin{tabular}{cl}
\hline Metaphor & \multicolumn{1}{c}{ Entailment } \\
\hline \multirow{2}{*}{ Looking after a cat at home } & $\begin{array}{l}\text { If you do not spend enough time with your cat, it will } \\
\text { be vexed with you. English is the same. If you do not } \\
\text { spend enough time with English, you will easily forget }\end{array}$ \\
it. & $\begin{array}{l}\text { The topics covered in English lessons are all related to } \\
\text { each other. }\end{array}$ \\
\hline
\end{tabular}

\subsection{Learners' Metaphors}

The second research question of the study is "What are the metaphors produced by young EFL learners about learning English?" It was found that out of 109 metaphors, negative metaphors of the young learners $(n=49,45 \%)$ clearly constitute the largest group. These metaphors illustrated in Table 5 imply that participating learners held the belief that it is either very difficult or impossible to learn the language. On the other hand, one interesting negative learner metaphor (e.g, Being the colony of another country) revealed the concern that English has to be learnt because it is the language of the "powerful". 
Table 5. Learners' Negative Metaphors Regarding English Learning

\begin{tabular}{|c|c|}
\hline Metaphor & Entailment \\
\hline Swimming against the tide & It is a waste of time as you cannot do it. \\
\hline The sky & $\begin{array}{l}\text { It has no limits. There is always something to learn in } \\
\text { English. }\end{array}$ \\
\hline Being able to walk on the water & $\begin{array}{l}\text { Both walking on the water and learning English are } \\
\text { impossible. }\end{array}$ \\
\hline My rucksack & I have had to carry this heavy bag for ages. \\
\hline The question "Do you like your mum or dad?" & $\begin{array}{l}\text { You just become graveled when you are asked this } \\
\text { question. }\end{array}$ \\
\hline Being the colony of another country & $\begin{array}{l}\text { In countries colonized by the powerful country, the rules } \\
\text { set by this country have to be abided by. That is why we } \\
\text { have to learn English. }\end{array}$ \\
\hline
\end{tabular}

As presented in Table 6, positive metaphors make up the second largest group. Positive metaphors focusing on the property of English as a survival language were generated by 31 learners (29\%).

Table 6. Learners' Positive Metaphors Regarding English Learning

\begin{tabular}{cl}
\hline Metaphor & \multicolumn{1}{c}{ Entailment } \\
\hline A skeleton key & $\begin{array}{l}\text { It can open all the doors. } \\
\text { You can fly anywhere you want. If you know English, } \\
\text { you are always in a more advantageous position than } \\
\text { Having wing }\end{array}$ \\
Water on the dessert & You can survive with it. \\
\hline
\end{tabular}

Ambivalent metaphors as shown in Table 7 were produced by 20 (18\%) learners expressing both negative and positive sides of the English learning process.

Table 7. Learners' Ambivalent Metaphors Regarding English Learning

\begin{tabular}{cl}
\hline Metaphor & \multicolumn{1}{c}{ Entailment } \\
\hline A map & $\begin{array}{l}\text { When you first look at a map, it looks very } \\
\text { complicated but when you look into it deeper, you } \\
\text { will understand that the map is easy. }\end{array}$ \\
It is difficult to buy an expensive dress but when you \\
buy it, you can enjoy it. \\
It is laborious but it is a great feeling to see flowers \\
blossom.
\end{tabular}

Only nine (8\%) learners were found to be neutral about the English learning process. As one can understand from Table 8 , they focused on the factual realities of the English learning process and expressed their metaphors without any emotions.

Table 8. Learners' Neutral Metaphors Regarding English Learning

\begin{tabular}{cl}
\hline Metaphor & \multicolumn{1}{c}{ Entailment } \\
\hline Eating strawberry & $\begin{array}{l}\text { If you do not eat it in its natural season, you cannot } \\
\text { get the taste of it. If you do not learn English at an } \\
\text { early age, you cannot learn it later. } \\
\text { You can climb the stairs one by one to reach the top. }\end{array}$ \\
\hline
\end{tabular}

Finally, the third research question of the study is "Is there any significant relationship between the numbers of positive/negative metaphors produced by parents and their children?" Therefore, after the analysis of parents and learners' metaphorical categories separately above, the researcher wanted to further analyze the relationship between parents and students' perceptions about learning English. As stated before, 66 parents with children attending 8th grade in a state school took part in the study. Out of all the participating parents, 32 produced positive metaphors and 18 came up with negative metaphors while the remaining parents produced either ambivalent $(n=9)$ or neutral metaphors $(n=7)$. Among the 32 parents who produced positive types of metaphors, 23 of their children similarly created positive metaphors. Among the 18 parents producing negative metaphors, more than half of their children $(n=13)$ also used negative metaphors.

Table 9 below illustrates the results of the Pearson product-moment correlation analysis conducted to reveal whether there is a significant relationship between the numbers of positive/negative metaphors of parents and their children about the English language learning process. As can be seen on Table 9, the Pearson correlation coefficient is .841 revealing that there is a significant positive correlation between the numbers of positive and negative metaphors produced by parents and their English learning children $(\mathrm{p}<.05)$. In other words, parents' 
perceptions about learning English influence their children' perceptions.

Table 9. Results of Pearson Product-Moment Correlation Analysis

\begin{tabular}{llcc}
\hline & & Parent & Learner \\
\hline Parent & Pearson Correlation & 1 &, $841^{* *}$ \\
& Sig. (2-tailed) & &, 000 \\
\multirow{3}{*}{ Learner } & $\mathrm{N}$ & 66 & 66 \\
& Pearson Correlation &, $841^{* *}$ & 1 \\
& Sig. (2-tailed) &, 000 & 66 \\
\hline
\end{tabular}

**. Correlation is significant at the 0.01 level (2-tailed).

\section{Discussion}

Inspired by the conceptual metaphor theory (Lakoff \& Johnson, 1980) arguing that the underlying nature of our thinking processes is metaphorical, and metaphors are the guides of our perceptions (Cornelissen et al., 2008), this study was an attempt to find out the metaphors young learners and their parents produce about learning English. The analysis of the metaphors under four categories (i.e. positive, negative, neutral or ambivalent) showed that parents had more positive attitudes than learners did. Parents' metaphors generally indicated the importance of the English as a global language. As reflected in the metaphors "ID card" and "Becoming a world citizen", it could be realized that parents were well aware of the globalized nature of the English language. Still, some parents emphasized the challenging face of the learning process by generating metaphors and entailments like "Learning English is like life itself because it is a long and arduous process" implying that learners face many challenges while learning the language.

Learners, on the other hand, were mostly negative towards learning English as the majority of them generated metaphors like "swimming against the tide" while there were some learners who indicated in their metaphors (e.g., A skeleton key) that English is vital as a means to seize many opportunities. The findings of the present study with Turkish parents and young EFL learners corroborate with studies carried out both in Turkey and abroad. For example, Aktekin's (2013) metaphorical category "Activity which requires practice and/or patience", the metaphorical categories such as "cultivation" found by Cortazzi and Jin (1996, as cited in Oxford et al., 1998), Caballero's (2006) "journey" category and "struggle" and "suffering" categories found by Ellis (2002) all refer to the challenging nature of the foreign language learning process. Similar to some of the young learners in Jin et al.'s (2014) study, many learners in this study produced metaphors indicating the difficulties of learning English. According to the report by TEPAV (The Economic Policy Research Foundation of Turkey) and British Council (2014), what causes disengagement, frustration and lack of motivation for most young EFL learners in the process of learning English in Turkey is their repeated exposure to the same grammar structures each year with no progress in useful listening or speaking skills by 8 th grade. The perception of some of the participants that the process of learning English is full of challenges can be justified by this important finding of TEPAV and British Council (2014).

As pointed out by Eroz and Akbarov (2014), learners' success is based on on the teacher-learner-parent triangle. Therefore, this study has implications for EFL learners, teachers as well as parents who all share important responsibilities to encourage young learners to learn English. As far as learners are concerned, it would be fair to state that the results of the current paper would be more promising if the learners taking part in the study produced more positive metaphors towards learning English. Learners' perceptions are very important in terms of the outcomes of their learning process (Gömleksiz, 2010) and as Gardner (1985) pointed out, positive attitudes lead to better foreign language proficiency. When learners develop positive attitudes towards learning English, they can more actively participate in classroom activities (Mirici, 2010). As also stated by Elyıldırım and Ashton (2006), learners with positive attitudes generally make more rapid progress learning the foreign language and exert greater efforts to accomplish their language learning goals. Therefore, it is recommendable that young EFL learners should be trained at the beginning of each academic year through an orientation program aiming to guide them to have more positive attitudes towards English. Awareness-raising activities contributing to learners' motivation, foreign language learning strategy training exercises and videos as well as guest speakers emphasizing the importance and ways of learning English can be integrated as components of such an orientation program. For a positive change in the attitudes of young learners towards learning English in Turkey, Kizıltan and Atlı (2013) suggest that a Language Attitude Form should be filled out before and after teaching for a certain amount of time to check young EFL learners' attitudes towards English lessons. They also emphasized the need to take young learners' attitudes towards English into account while preparing the foreign EFL curriculum at the beginning of each academic year. Likewise, Gömleksiz (2010) underlines that English teachers must be well aware of the problems learners face during the language learning process and before starting to teach, they should train their students about the importance of English. As far as the importance of English is concerned, TEPAV 
and British Council (2014) go one step further by calling for a national campaign in Turkey to raise the awareness of young EFL learners and parents about the importance of communication in English.

It is also argued that the teachers' role in the success of the young learners in learning English cannot be denied, and it is vital for teachers teaching EFL to young learners to have the formation required to teach this specific group of learners (Bayyurt, 2012). It is important for these teachers to be able to create a positive learning environment by considering the specific characteristics of young EFL learners having lots of energy and emotional needs (Brewster, Ellis \& Girard, 2011). As claimed by Klein (2005), teaching EFL to young learners is different from teaching adults as the mood of the young learners might change any minute, and their levels of motivation, curiosity and enthusiasm are higher than that of the adults. Therefore, to train EFL teachers in line with appropriate pedagogy to teach English to young learners, Erkan (2010) proposes that in-service training dealing with modern EFL teaching methods to teach young learners should be organized in Turkey. Similarly, Er (2014) calls for more seminars informing English teachers about teaching strategies to young learners. On the other hand, Aydın (2012) recommends that the pre-service English teacher training program in Turkey is also in need of revision specifically in terms of teaching EFL to young learners.

Another noteworthy finding of the present study is that learners' perceptions of the English language learning process are mostly dependent on the perceptions of their parents. The correlation analysis of the numbers of positive/negative metaphors produced by parents and their children revealed that if the parent is positive towards learning English, his/her child mostly reflects a positive attitude as well and vice-versa. Thus, it would be fair to suggest that parents have important responsibilities to raise their children's motivation and lead them to think more positively about language learning. To illustrate, there is a need for more parents' involvement in the language learning process of their children as they can help their children to perceive this process more positively. It was concluded in many studies worldwide that parents' engagement and encouragement in the learning process of their children positively affect their motivation and thus their success at school (Sheldon, 2002; Roth, 2008; Clark \& Hawkins, 2010). It is also argued that children become more positive towards the learning process when their parents help them with their assignments, ask them questions regarding their foreign language lessons and try to learn the language with them (Cooper \& Maloof, 1999). Furthermore, it can be suggested that as two important agents who have the power to change learners' negative attitudes towards learning English, parents and teachers should be in close cooperation with each other (Christenson \& Sheridan, 2001). The family-school partnership not only increases learners' success and motivation to learn English, but also has the potential to lead to positive changes in parents' attitudes towards learning the English language.

It would be wise to end the paper with a call for more metaphor studies in different contexts with larger samplings of participants so that the obstacles in the English language learning process can be better diagnosed and treated. Metaphors produced by learners and parents provide English teachers with useful insights to be able to effectively cope with language learning problems. The data obtained through metaphors contribute not only to the professional development of the English teachers as metaphors reveal problematic aspects of the learning process (Ellis \& Barkhuizen, 2005), but also to other relevant stakeholders like curriculum and materials developers. Above all, uncovering the metaphors of relevant stakeholders getting involved in the language learning process can lead to positive change in educational beliefs and even practices (Cameron, 2003). I would like to finalize the article with a nice saying of Shuell (1990, p. 102): "If a picture is worth 1,000 words, a metaphor is worth 1,000 pictures!"

\section{References}

Aktekin, N. Ç. (2013). Revealing ESL teachers' and students' attitudes and beliefs through metaphors. Uludă University Journal of Education Faculty, 26, 405-422.

Aragao, R. (2011). Beliefs and emotions in foreign language learning. System, 39(3), 302-313. http://dx.doi.org/10.1016/j.system.2011.07.003

Arıkan, A. (2011). A small-scale study of primary school English language teachers' classroom activities and problems, 2nd International Conference on New Trends in Education and Their Implications, 27-29, Antalya.

Arıkan, A. (2015). An autoethnography of teaching English to young learners: From theory to practice. The Anthropologist, 20(1/2), 77-85.

Aydın, S. (2012). Factors causing demotivation in EFL teaching process: A case study. The Qualitative Report, 17, 1-13.

Bayyurt, Y. (2012). 4+4+4 eğitim sisteminde erken yaşta yabancı dil eğitimi. Paper presented at the 1st Hacettepe University Foreign Language Education Workshop, Ankara, Turkey.

Berry, R. (2004). Awareness of metalanguage. Language Awareness, 13(1), 1-16. http://dx.doi.org/10.1080/09658410408667082

Brewster, J., Ellis, G., \& Girard, D. (2011). The primary English teacher's guide (New Edition). Essex: Penguin English 
Guides.

Caballero, R. (2006). Journey metaphors in foreign language teaching-learning: Ways of travelling/learning in multimedia environments. Mélanges CRAPEL, 28, 201-209.

Cameron, L. (2003). Metaphor in educational discourse. London: Continuum.

Cameron, L., \& Low, G. (1999). Metaphor. Language Teaching, $32 \quad$ (2), 77-96. http://dx.doi.org/10.1017/S0261444800013781.

Çap, R. C., \& Acat, M. B. (2012). Reflection of culture: Metaphor usage in teaching English as a Second Language. Eğitimde Politika Analizi Dergisi, 1(2), 134-143.

Çapan, E. B. (2010). Öğretmen adaylarının üstün yetenekli öğrencilere ilişkin metaforik algıları. The Journal of International Social Research, 3(12), 140-154.

Çelebi, M. D. (2006). Türkiye'de anadili eğitimi ve yabancı dil öğretimi, Erciyes Üniversitesi Sosyal Bilimler Enstitüsü Dergisi, 2(21), 285-307.

Christenson, S. L., \& Sheridan, S. M. (2001). School and families: Creating essential connections for learning. NY: Guilford Press.

Clark, C., \& Hawkins, L. (2010). Young people's reading: The importance of the home environment family support. National Literacy Trust, 1-32.

Cochran, S. M. (2002). The research base for teacher education metaphors we live (and die?). Journal of Teacher Education, 53(4), 283-285. http://dx.doi.org/10.1177/0022487102053004001

Cooper, T. C., \& Maloof, V. M. (1999). Parent involvement in teaching elementary-level Chinese, Japanese, and Korean. Journal of Educational Research, 92(3), 176 183.http://dx.doi.org/10.1080/00220679909597593

Cornelissen, J. P., Oswick, C., Christensen, L. T., \& Phillips, N. (2008). Metaphor in organizational research: Context, modalities and implications for research-Introduction. Organization Studies, $29(1)$, 7-22. http://dx.doi.org/10.1177/0170840607086634

Cortazzi, M., \& Jin, L. (1996). Metaphors of teaching, learning and language. Paper presented at the Symposium of Applying Metaphor, University of New York.

Council of Europe. (2001). Common European Framework of Reference for Languages (CEFR): Learning, Teaching, Assessment, Modern Language Division, Strasbourg.

De Guerrero, M. C., \& Villamil, O. S. (2002). Metaphorical conceptualizations of ESL teaching and learning. Language teaching research, 6(2), 95-120. http://dx.doi.org/10.1191/13621688021r101oa

Ellis, R. (2002). A metaphorical analysis of learner beliefs. In P. Burmeister, T. Piske and A. Rohde (Eds.), An integrated view of language development: Papers in honor of Henning Wode. Trier, Germany: Wissenschaftlicher Verlag.

Ellis, R., \& Barkhuizen, G. (2005). Analysing learner language. Oxford: Oxford University Press.

Elyıldırım, S., \& Ashton, S. (2006). Creating positive attitudes towards English as a foreign language. English Teaching Forum, 44(44), 2-11.

Er, S. (2014). Which is the most appropriate strategy for very young language learners? International Journal of Social Sciences and Education, 4(4), 829-837.

Erkan, S. S. Ş. (2012). Problems of English language instruction in primary in Turkey and their suggestions. Procedia Social and Behavioral Sciences, 1(46), 1106-1111. http://dx.doi.org/10.1016/j.sbspro.2012.05.258

Eroz, E. \& Akbarov, A.A. (2014). The efficacy of teacher-parent rapport on Bosnian high school students' English language skills. Mediterranean Journal of Social Sciences, 5(4), 656-661.

Ersöz, A. (2007). Teaching English to young learners. Ankara: EDM Publishing.

Fortune, A. (2005). Learners' use of metalanguage in collaborative form focused L2 output tasks. Language Awareness, 14(1), 21-38. http://dx.doi.org/10.1080/09658410508668818

Gardner, R. (1985). Social psychology and second language learning: The role of attitude and motivation. London: Edward Arnold.

Goldstein, L. B. (2005). Becoming a teacher as a hero's journey: Using metaphor in preservice teacher education. Teacher Education Quarterly, 32(1), 7-24. 
Gömleksiz, M. (2010). An evaluation of students' attitudes towards English language learning in terms of several variables. Procedia Social and Behavioral Sciences, 9, 913-918. http://dx.doi.org/10.1016/j.sbspro.2010.12.258

Guerrero, M. C. M. \& Villamil, O. S. (2002). Metaphorical conceptualizations of ESL teaching and learning. Language Teaching Research, 6(2), 95-120. http://dx.doi.org/10.1191/13621688021r101oa

Gürsoy, E., Korkmaz, S. Ç., \& Damar, A. E. (2013). Foreign language teaching within 4+4+4 education system in Turkey: Language teachers' voice. Eurasian Journal of Educational Research, 53/A, 59-74

Işık, A. (2008). Yabancı dil eğitimizdeki yanlışlıklar nereden kaynaklanıyor? Journal of Language and Linguistic Studies, 4(2), 15-26.

Jin, L., Smith, K., Yahya, A., Chan, A., Choong, M., Lee, V., Ng, V., Poh-Wong, P., \& Young, D. (2013). Perceptions and Strategies of Learning in English by Singapore Primary School Children with Dyslexia - a metaphor analysis, in Sheehan, S (ed) British Council ELT Research Papers Vol. 1. London: British Council.

Jin, L., Liang, X., Jiang, C., Zhang, J., Yuan, Y., \& Xie, Q. (2014). Studying motivations of Chinese young EFL learners through metaphor analysis. ELT Journal, 68(3), 286-298. http://dx.doi.org/10.1093/elt/ccu011

Kesen, A. (2010). Turkish EFL learners' metaphors with respect to English language coursebooks. Novitas-ROYAL: Research on Youth and Language, 4(1), 108-118. Retrieved from http://novitasroyal.org/Vol_4_1/kesen.pdf

Kırkgöz, Y. (2008). A case study of teachers' implementation of curriculum innovation in English language teaching in Turkish primary education. Teaching and Teacher Education, 24, 1859-1875. http://dx.doi.org/10.1016/j.tate.2008.02.007

Kiziltan, N., \& Atl1, I. (2013). Turkish young language learners' attitudes towards English. Hacettepe University Journal of Education, 28(2), 266-278.

Klein, K. (2005). Teaching young learners. English Teaching Forum, 43(1), 12-17.

Lakoff, G., \& Johnson, M. (1980). Metaphors we live by. Chicago: University of Chicago Press.

Liao, P. (2006). EFL learners' beliefs about and strategy use of translation in English learning. RELC Journal, 37(2), 191-215.http://dx.doi.org/10.1177/0033688206067428

Mirici, I. H. (2010). Influence of prestudy on foreign language learning attitude. Social Behavior and Personality, 38(2), 187-196. http://dx.doi.org/10.2224/sbp.2010.38.2.187

Nikitina, L. \& Furuoka, F. (2008). Measuring metaphors: a factor analysis of students' conceptions of language teachers. Metaphor.de, 15, 161-180.

Önen, A. S., \& Koçak, C. (2011). Candidate teachers' tour in campus with their metaphoric images. Procedia Social and Behavioral Sciences, 15, 3555-3559. http://dx.doi.org/10.1016/j.sbspro.2011.04.334

Oxford, R., Tomlinson, S., Barcelos, A., Harrington, C., Lavine, R. Z., \& Saleh, A. (1998). Clashing metaphors about classroom teachers: Toward a systematic typology for the language teaching field. System, 26(1), 3-50. http://dx.doi.org/10.1016/S0346-251X(97)00071-7

Roth, B. (2008). The importance of parental encouragement and support. http://ezinearticles.com/?The-Importance-of-Parental-Encouragement-andSupport\&id=1622042

Seferoğlu, G., Korkmazgil, S., \& Ölçü, Z. (2009). Gaining insights into teachers' ways of thinking via metaphors. Educational Studies, 35(3), 323-335. http://dx.doi.org/10.1080/03055690802648135

Sheldon, S. B. (2002). Parents' social networks beliefs as predictors of parent involvement. The Elementary School Journal, 102, 301-316. http://dx.doi.org/10.1086/499705

Shuell, T. J. (1990). Teaching and learning as problem solving. Theory into Practice, 29, 102-108. http://dx.doi.org/10.1080/00405849009543439

Şaban, A. (2004). Giriş düzeyindeki sınıf öğretmeni adaylarının "öğretmen” kavramına ilişkin ileri sürdükleri metaforlar. Türk Ĕ̈itim Bilimleri Dergisi, 2(2), 131-155.

Şimşek, M. R. (2014). A metaphor analysis of English teacher candidates' pre- and post-course beliefs about language and teaching. Dicle Üniversitesi Ziya Gökalp Eğitim Fakültesi Dergisi, 22, 230-247.

T. C. Milli Eğitim Bakanlığı, Talim ve Terbiye Kurulu Başkanlığı. (2013). İlköğretim kurumları (ilkokullar ve ortaokullar) İngilizce dersi (2, 3, 4, 5, 6, 7 ve 8. sinfflar) öğretim programı. Ankara: T.C. Milli Ĕgitim Bakanlı̆̆ı.

TEPAV \& British Council. (2014). Turkish national needs assessment of state school English language teaching. Ankara: Yorum Basın Yayın. Retrieved from 
http://www.tepav.org.tr/upload/files/1399388356-5.Turkey_National_Needs_Assessment_of_State_School_Englis h_Language_Teaching.pdf

Torghabeh, R.A., Elahi, M., \& Khanalipour, S. (2009). Examining Iranian EFL learners' and teachers' beliefs about teachers through metaphor analysis. Iranian EFL Journal, 5, 115-138.

Wan, W., Low, G. D., \& Li, M. (2011). From students' and teachers' perspectives: Metaphor analysis of beliefs about EFL teachers' roles. System, 39(3), 403-415. http://dx.doi.org/10.1016/j.system.2011.07.012

Yıldırım, A., \& Şimşek H. (2005). Sosyal bilimlerde nitel araştırma. (5nd ed.) Ankara: Seçkin Yayınları.

Yob, I. M. (2003). Thinking constructively with metaphors. Studies in Philosophy and Education, 22, $127-138$. http://dx.doi.org/10.1023/A:1022289113443

\section{$(\mathrm{cc}) \mathrm{EY}$}

This work is licensed under a Creative Commons Attribution 3.0 License. 